DUŠAN Ž. MIJIN*, DUNJA M. DABIĆ, JELENA M. MIRKOVIĆ, BOJAN Đ. BOŽIĆ, BRANIMIR N. GRGUR

University of Belgrade, Faculty of Technology and Metallurgy, Belgrade, Serbia
Scientific paper

ISSN 0351-9465, E-ISSN 2466-2585

UDC:620.183.4

doi:10.5937/ZasMat1601063M

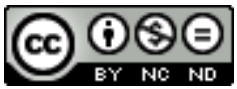

Zastita Materijala 57 (1)

$63-70(2016)$

\title{
Influence of microwave irradiation on hypochlorite decolorisation of synthetic dyes
}

\begin{abstract}
In this study three synthetic dyes were treated using hypochlorite or combination of hypochlorite and microwave irradiation in order to investigate factors which determine decolorisation of the investigated compounds. An azo dye (C.I. Reactive Orange 16-RO16), an azo methine dye (C.I. Basic Yellow 28 - BY28) and an antraquinone dye (C.I. Acid Blue 111 - AB111) were used for experiments. Hypochlorite stability as well as the influence of microwaves on hypochlorite stability was also investigated.
\end{abstract}

Keywords: Dye decolorisation, sodium chloride, azo dye, antraquinone dye, azomethine dye, waste water, microwave reactor

\section{INTRODUCTION}

In many countries, as a result of production and use of dyes, the effluents of a variety of industries contain synthetic organic dyes. These industries include textile, leather, paper, food and hair coloring industry [1-5]. Dyes, which are colored, cause not only aesthetic pollution but can be serious health-risk factors [6,7]. Dyes can be classified by their application to substrate or by their chemical structure. The first classification includes direct, reactive, disperse, vat, azoic dyes etc. The second one includes azo, anthraquinone, nitro and nitroso, di - and triarylmethine, polyene and polymethine, carbonyl, sulfur dyes etc. [8,9]. Azo dyes represent the most important class of colorants. More than $50 \%$ of all dyes and pigments contain azo group. The second commercially important group belongs to anthraquinone dyes $[10,11]$.

Dyes can be removed by chemical and physical processes, which include adsorption, filtration, ozonation, bleaching, oxidative degradation photochemical processes and electrochemical degradation [7,12-14]. Bleaching, as one of the process for

\footnotetext{
*Corresponding author: Dušan Mijin

E-mail: kavur@tmf.bg.ac.rs

Paper received: 17. 10. 2015.

Paper accepted: 30. 11. 2015.

Paper is available on the website: www.idk.org.rs/casopis
}

pollutant removal, includes use of oxidizing agents like sodium hypochlorite, hydrogen peroxide or peracids. Hypochlorite $(\mathrm{HOCl})$ is the most aggressive and most efficient oxidant. It is very reactive towards dyes. The active species in bleaching are aqueous chlorine (at low $\mathrm{pH}$ ) and undissociated hypochlorite $(\mathrm{pH} 4-10.5)$ [15]:

$$
\begin{aligned}
& \mathrm{HOCl}=\mathrm{H}^{+}+\mathrm{OCl}\left(p K_{A}=7.5\right) \\
& \mathrm{HOCl}+\mathrm{Cl}+\mathrm{H}^{+}=\mathrm{Cl}_{2}+\mathrm{H}_{2} \mathrm{O}(p K=3.3)
\end{aligned}
$$

Microwave (MW) radiation is an electromagnetic radiation placed between infrared radiation and radio frequencies, with wavelength of $1 \mathrm{~mm}$ to $1 \mathrm{~m}$. This corresponds to the frequencies of 300 $\mathrm{GHz}$ to $300 \mathrm{MHz}$, respectively. In order to avoid interferences with telecommunication devices, household and industrial microwave ovens are operated at either $12.2 \mathrm{~cm}(2.45 \mathrm{GHz})$ or $32.7 \mathrm{~cm}$ (915 $\mathrm{MHz}$ ). Usually domestic microwave ovens operate at $2.45 \mathrm{GHz}$, and for that reason all commercial microwave reactors operate at the same frequency [16].

In comparison to conventional heating, MW irradiation has certain advantages. It exhibits higher heating rates, increased reaction rates, reduced activation energies, improved energy efficiency and reduced equipment size. MW irradiation is also selective and has excellent controllability, while application in sample preparation, organic and inorganic synthesis, food processing, sludge processing, medical waste treatment, contaminated soil remediation, wastewater treatment etc were observed [17-19]. 
Organic pollutants which have been treated by microwave technology include dyes [20-22], phenolic compounds [23], pharmaceuticals [24], volatile organic compounds [25]. MW irradiation is usually combined with oxidants [17,26,27], or adsorbents [28]. Also different catalyst were used like nickel nanoparticles [29], fly ash zeolites [30], $\mathrm{NiFe}_{2} \mathrm{O}_{4}$ [31], polyaniline [32] and $\mathrm{TiO}_{2}$ [33].

To the our best knowledge, until now, hypochlorite has not been combined with microwave irradiation. So, in this study, combined application of hypochlorite and microwave irradiation in the decolorisation of the synthetic dyes from the water solution were performed. As synthetic dyes, an azo dye (C.I. Reactive Orange 16 - RO16), an azo methine dye (C.I. Basic Yellow 28 - BY28) and an antraquinone dye (C.I. Acid Blue 111 - AB111) were used. The structures of the studied dyes are given in Figure 1. The influence of microwaves on the hypochlorite stability was also investigated.

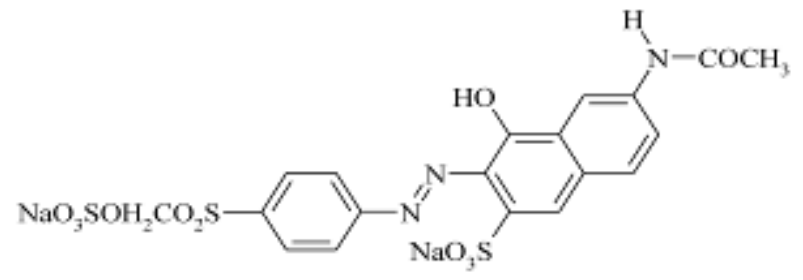

C.I. Reactive Orange 16<smiles>COc1ccc(N(C)/C=N/C2=[N+](C)c3ccccc3C2(C)C)cc1</smiles>

C.I. Basic Yellow 28<smiles>CCOC(=O)c1ccccc1Cc1ccc(Nc2cc(S(=O)(=O)O)c(N)c3c2C(=O)c2ccccc2C3=O)c(C)c1</smiles>

C.I. Acid Blue 111

Figure 1 - The structures of the studied dyes

\section{EXPERIMENTAL}

\subsection{Materials and methods}

All starting materials were obtained from Aldrich and Fluka, and were used without further purification. The textile dyes were obtained as follows: $\mathrm{Cl}$ Reactive Orange 16 from Aldrich (dye content 50\%); Cl Basic Yellow 28 from Bezema (commercial name Bezacryl Goldgelb GL 200) and C.I. Acid Blue 111 from Hoechst (commercial name Fast Blue FGLL). The dyes were used without purification. Sodium chloride was p.a. grade (Merck). Deionised water was obtained from a Milipore Waters Milli-Q purification unit.

\subsection{Preparation of hypochlorite}

Preparation of hypochlorite was performed in the cylindrical glass electrochemical cell with electrolyte volume of $500 \mathrm{~cm}^{3}$. Electrolyte was prepared from deionised water and $\mathrm{NaCl}$. As anode $5 \mathrm{~cm}^{2}$ DSA Ti/PtOx, obtained by thermal decomposition of $\mathrm{H}_{2} \mathrm{PtCl}_{6}$ in 2-propanol with $1 \mathrm{mg} \mathrm{cm}^{-2}$ of platinum loading, was used, while cathode was 10 $\mathrm{cm}^{2}$ plate made from austenite $18 \mathrm{Cr} / 8 \mathrm{Ni}$ stainless steel series 304 [34]. Electrode with the gap of 3 $\mathrm{mm}$ was immersed at the top of the electrolyte. For the electrolysis of solution galvanostatic mode of PAR M273 potentiostat/galvanostat was used. Mixing of the electrolyte by magnetic stirrer was accomplished. During the electrolysis, at $5 \mathrm{~min}$ interval time $3 \mathrm{~cm}^{3}$ of solution had been taken with pipette and UV-Vis spectra was instantly recorded. The concentration of the hypochlorite was followed by measuring the absorption of solution using UVVis spectrophotometer (Shimadzu model 1700 spectrophotometer). The concentration of hypochlorite was calculated using Faraday law [35].

\subsection{Decolorization using hypochlorite}

The decolorization process in thermostated cylindrical glass with reaction mixture volume of 100 $\mathrm{cm}^{3}$ was investigated. The reaction mixture was prepared by mixing of dye solution with hypochlorite solution to obtain desired concentrations. Mixing of the reaction mixture was accomplished by magnetic stirrer at $600 \mathrm{rpm}$. During the decolorisation at certain times $3 \mathrm{~cm}^{3}$ of solution was taken with pipette and UV-Vis spectra was instantly recorded. The concentration of dye was followed by measuring the absorption of solution using UV-Vis spectrophotometer.

\subsection{Decolorization using hypochlorite under microwave irradiation}

The decolorization process in a microwave reactor (Anton Paar Monowave 300) with reaction mixture volume of $6 \mathrm{~cm}^{3}$ was investigated. The reaction mixture was prepared by mixing of dye solution with hypochlorite solution to obtain desired concentrations. The reaction mixture was stirred at $600 \mathrm{rpm}$ and irradiated for a certain period of time at appropriate temperature. The progress of the reaction was followed by UV-Vis spectrophotometer. 


\section{RESULTS AND DISCUSION}

\subsection{Hypochlorite generation}

In the first part of the presented study, the sodium hypochlorite solution by electrolysis of $\mathrm{NaCl}$ was prepared, as described in Experimental part. The formation of hypochlorite was followed by UVVis spectrophotometer at $292 \mathrm{~nm}$, and the concentration of hypochlorite solution was determined according to Faraday law (Figure 2) [35]. The obtained solutions were kept in dark bottles at $4^{\circ} \mathrm{C}$.

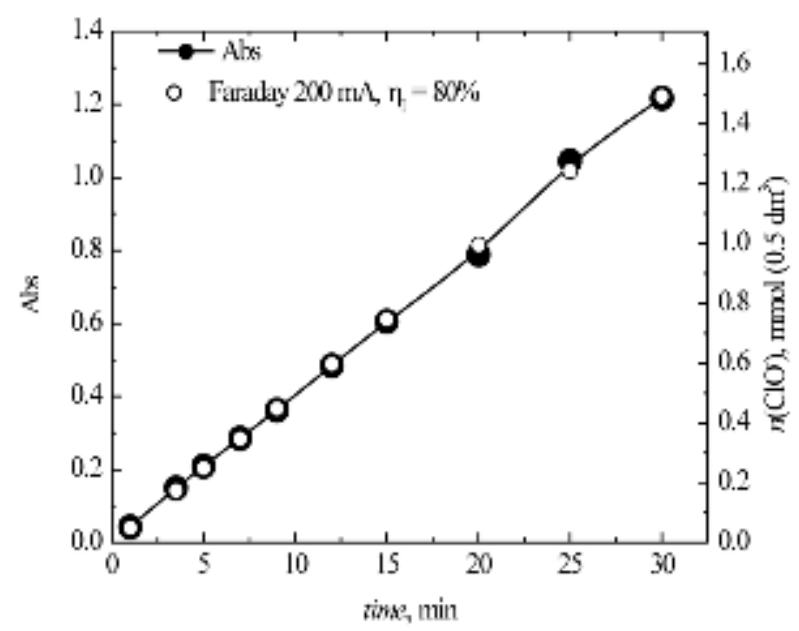

Figure 2 - Dependence of absorbance and hypochlorite concentration of electrolysis time (sodium chloride concentration $=20 \mathrm{~g} \mathrm{dm}^{-3}$, current $=200 \mathrm{~mA}$ ).

\subsection{Stability of hypochlorite}

Used $\mathrm{NaOCl}$ solution was prepared daily, since the results of hypochlorite stability (Figure 3 ) indicated that $\mathrm{NaOCl}$ solution was quite unstable.

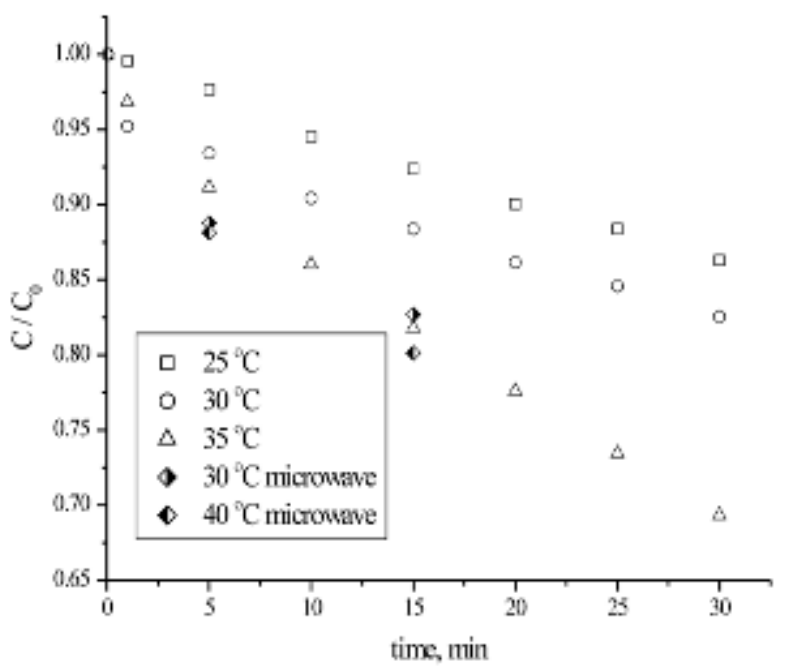

Figure 3 - Stability of hypochlorite at different temperatures (hypochlorite concentration $=0.375$ $\mathrm{mmol} \mathrm{dm}^{-3}$ )
The main reason of instability is catalytic disproportionation with trace impurities of hypochlorite, especially at elevated temperatures, according to equation [36]:

$$
3 \mathrm{ClO}^{-}=\mathrm{ClO}_{3}^{-}+2 \mathrm{Cr}
$$

The $\mathrm{pH}$ of solution was around 9 after electrolysis. Obviously, the diluted $\mathrm{NaOCl}$ solutions were degraded rapidly, and the degradation rate increased with temperature. Generally, around $12.5 \%$ of $\mathrm{NaOCl}$ was lost after $30 \mathrm{~min}$ at $25{ }^{\circ} \mathrm{C}$, while at $35{ }^{\circ} \mathrm{C}$ more than $30 \%$ was degraded for the same period of time. Application of microwave irradiation did not have significant influence on the degradation of hypochlorite in comparison to conventional heating (around $12.5 \%$ after $5 \mathrm{~min}$, and around $20 \%$ after $15 \mathrm{~min}$ ).

\subsection{UV-Vis spectra}

The UV-Vis spectra changes, during decolorization of the studied dyes, are presented in Figure 4. Figure 4a shows UV-Vis spectra changes of RO16 during reaction with hypochlorite. The peak at $295 \mathrm{~nm}$ in the spectrum of the RO16 corresponds to the gamma acetylated acid structure, a precursor in R016 synthesis. The peaks at 254 and $386 \mathrm{~nm}$ are indicative of benzene ring and azo group, respectively. At the end, due to an azo-hidrazone tautomerism in R016 molecule, the peak at $493 \mathrm{~nm}$ corresponds to the hydrazone form of the dye [37]. The decolorization of RO16 dye can be easily observed by decrease of the absorption peaks at 386 and $493 \mathrm{~nm}$.

The UV-Vis spectra of BY28 (Figure 4b) is characterized by three peaks: at 257, 300 and 436 $\mathrm{nm}$. The first absorption band (at $257 \mathrm{~nm}$ ) is due to the $\left(\pi \rightarrow \pi^{*}\right)$ transition and is localized in the aromatic rings. The absorption band at $300 \mathrm{~nm}$ also corresponds to a $\left(\pi \rightarrow \pi^{*}\right)$ transition. The third absorption band at $436 \mathrm{~nm}$ is assigned to a $(\mathrm{n} \rightarrow$ $\left.\pi^{*}\right)$ transition [38]. The decrease of absorption peak actually indicates a decolorization of BY 28 dye.

The UV-Vis spectra of AB111 (Figure 4c) is characterized by absorption peak at $634 \mathrm{~nm}$ (and a shoulder at $589 \mathrm{~nm}$ ) which is result of amino groups presence. Amino groups as electron-donor cause an $\left(\pi \rightarrow \pi^{*}\right)$ absorption band which is assigned to a charge transfer transition. The position of this band is the result of the conjugation of the $2 p$ orbital of the nitrogen with the anthraquinone $\pi$ electronic system [39]. The absorption band at $391 \mathrm{~nm}$ can be assigned to a ( $\mathrm{n}$ $\left.\rightarrow \pi^{*}\right)$ transition. The absorption band at $254 \mathrm{~nm}$ corresponds to the $\left(\pi \rightarrow \pi^{*}\right)$ transition (aromatic rings) as given before. The decrease of absorption peaks in the visible region indicates a decolorization of $A B 111$ dye. 


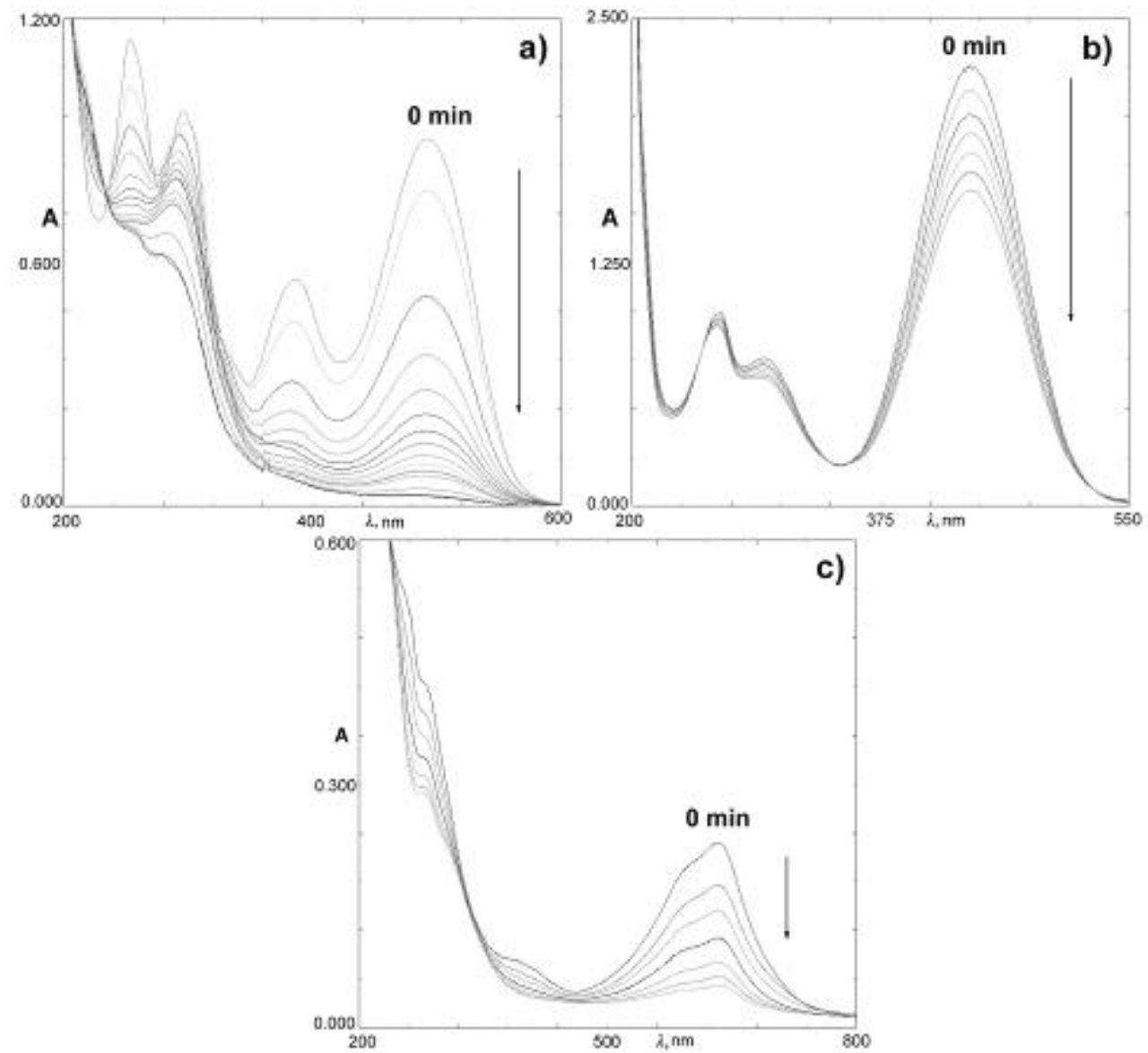

Figure 4 - a) UV-Vis absorption spectra of RO16 $\left(25^{\circ} \mathrm{C}\right.$, hypochlorite concentration $\left.=0.375 \mathrm{mmol} \mathrm{dm}^{-3}\right)$, b) UV-Vis absorption spectra of $B Y 28\left(40^{\circ} \mathrm{C}\right.$ hypochlorite concentration $\left.\left.=1.5 \mathrm{mmol} \mathrm{dm}{ }^{-3}\right), \mathrm{c}\right) \mathrm{UV}$-Vis absorption spectra of $A B 111\left(30^{\circ} \mathrm{C}\right.$, hypochlorite concentration $\left.=0.375 \mathrm{mmol} \mathrm{dm}^{-3}\right)$.

\subsection{Dye decolorisation using only hypochlorite}

It was mentioned earlier that azo-hidrazon tautomerism exists in RO16 molecule. The mechanism of decolorisation of one such molecule includes the conversion of hydrazone tautomer to hydrazone chloride $(\mathrm{N}(\mathrm{Cl})-\mathrm{N}=)$ which is considered to be the rate determining step of the reaction [40]. In addition, it was suggested that the ratedetermining step is the electrophilic attack of the chloronium ion $\left(\mathrm{Cl}^{+}\right)$on the nitrogen atom in the hydrazone tautomer [41]. The reaction then proceeds by $\mathrm{OCl}^{-}$attack on the imino group of hydrazone chloride which gives single bond between two nitrogens. The other mechanism was also proposed which includes attack of deprotonated hydrazone form $\left(\mathrm{N}^{-}\right)$on hypochlorous acid giving $\mathrm{Cl}^{-}$and hydrazone hydroxide $(\mathrm{NOH}-\mathrm{N}=)$. Hydrazone hydroxide then reacts with hydroxide anion which produces asymmetrical cleavage of azo bond [15]. Interruption of conjugation in molecule leads to the decolorization. Figure $5 \mathrm{a}$ shows the influence of reaction temperature on decolorisation. As it can be seen, decolorisation of around $90 \%$ can be achieved at $25^{\circ} \mathrm{C}$ after $15 \mathrm{~min}$, while an increase in temperature increases the decolorisation rate and slightly increases the percentage of decolorisation.

The similar behavior was observed when AB111 dye was concerned, but the decolorisation was less effective. It is well known that 1,4diaminoantraquinone exists as amino-imino tautomers [42]. This implies that here the reaction can also proceed by the electrophilic attack of the chloronium ion on the nitrogen atom. However, due to the structure of anthraquinone molecule (condensed rings) $A B 111$ is less susceptible to hypochlorite oxidation in comparison to RO16. Here, also an increase in temperature increases the decolorisation rate. The achieved percentage of decolorisation increases from $\sim 60 \%$ to more than 80\% (Figure $5 b$ ).

The lowest reactivity of the studied dyes was observed in the case of BY28 decolorisation. This dye is azomethine dye and, as such, is less reactive since the electrophilic attack of the chloronium ion on the nitrogen atom in BY28 is hindered by the conjugation which exists in the molecule (Figure 1). 

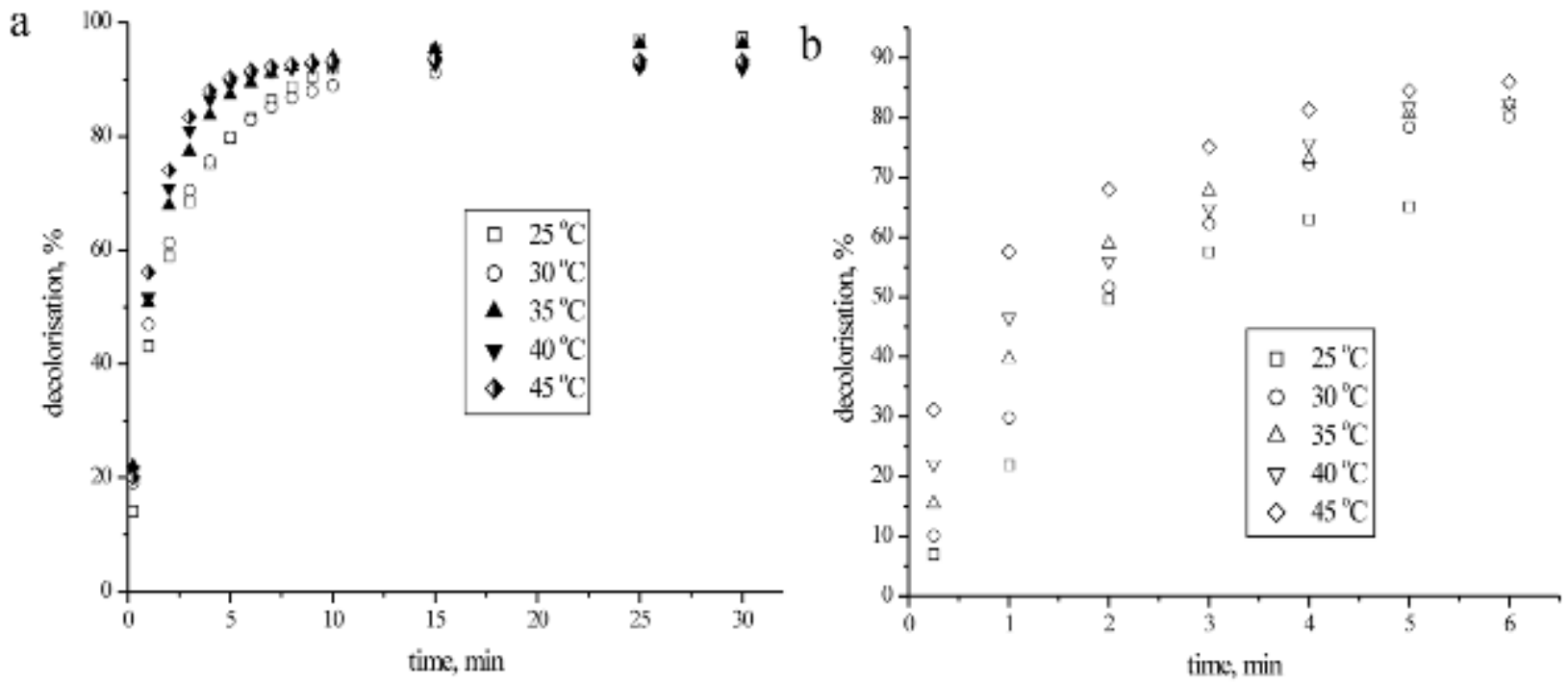

Figure 5 - Temperature effect on decolorisation of RO16 (a) and AB111 (b) dyes using only hypochlorite (dye concentration $=97 \mu \mathrm{mol} \mathrm{dm} \mathrm{m}^{-3}$, hypochlorite concentration $=0.375 \mathrm{mmol} \mathrm{dm}{ }^{-3}$ )

Due to this low reactivity of BY28 [38], only reaction at $40^{\circ} \mathrm{C}$ was recorded and compared to $\mathrm{RO} 16$ and $A B 111$ decolorisation under the same reaction conditions (Figure 6 ). It can be seen that the reactivity order is in accordance with the aforementioned, i.e. RO16>AB111>BY28.

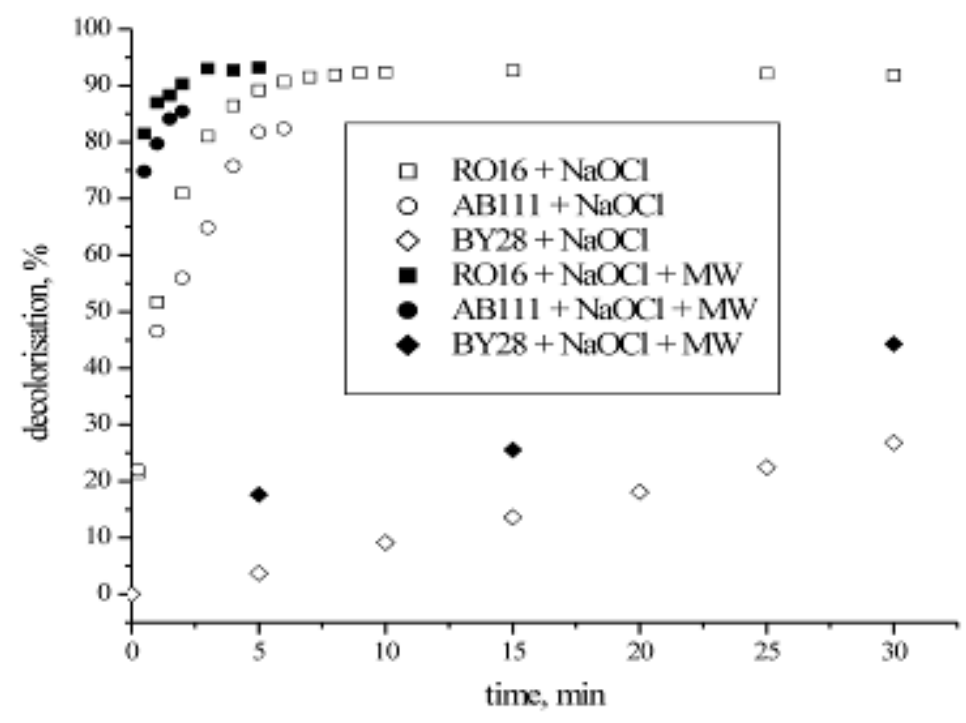

Figure 6 - Influence of dye structure on decolorisation using hypochlorite (empty symbols) and hypochlorite and microwave irradiation (full symbols) at $40^{\circ} \mathrm{C}$ (hypochlorite concentration $=0,375 \mathrm{mmol}$ $\mathrm{dm}^{-3}$ (RO16 i AB111) and $1.5 \mathrm{mmol} \mathrm{dm}^{-3}$ (BY28), dye concentration $=97 \mu \mathrm{mol} \mathrm{dm}^{-3}$ ).

\subsection{Dye decolorisation using hypochlorite and microwave irradiation}

In the final part of this research, influence of microwave irradiation on decolorisation of investigated dyes was studied (Figure 6). The microwave irradiation alone of aqueous solution of the studied dyes had no effect unless combined with hypochlorite. Microwave irradiation in combination with hypochlorite increases the reaction rate and efficiency of decolorisation. This effect is smaller in the case of RO16 dye but much pronounced in the case of AB111 dye. The microwave effect was also observed in the case of BY28 decolorisation. It was shown in the previous section that thermal effect was observed only when hypochlorite was used. Here, we have seen that the combination of microwave irradiation and hypochlorite enhanced the decolorisation process. This enhancement was 
observed in each microwave treatment of the studied dyes. The microwaves can have thermal and nonthermal (or specific) effects on the reaction. Thermal effects are caused by the heating rate, superheating, "hot spots" and the selective absorption of irradiation by polar substances [43]. So, the thermal and nonthermal effects were reported in the microwave degradation of Rhodamine-B photodegradation [44]. As nonthermal effect is quite hard to prove [45], it can be presumed that only thermal effect of microwave irradiation influence the rate and decolorisation efficiency of the used treatment. At the end, it should be pointed out that there is no difference in reactivity order of dyes in the reaction with pure hypochlorite or hypochlorite/microwave combination (Figure 6).

\section{CONCLUSION}

The sodium hypochlorite solution was prepared by electrolysis of $\mathrm{NaCl}$ and the concentration of hypochlorite solution was determined according to Faraday low. The diluted $\mathrm{NaOCl}$ solutions were degraded rapidly, and the degradation rate increased with temperature. Generally, around $12.5 \%$ of $\mathrm{NaOCl}$ was lost after $30 \mathrm{~min}$ at $25{ }^{\circ} \mathrm{C}$ while at $35^{\circ} \mathrm{C}$ more than $30 \%$ was degraded for the same reaction time. Application of microwave irradiation did not have significant influence on the degradation of hypochlorite in comparison to conventional heating. The reactivity order of the studied dyes was in accordance with the structure of dyes and their susceptibility to hypochlorite oxidation, i.e. RO16>AB111>BY28. The microwave irradiation alone of aqueous solution of the studied dyes have no effect unless combined with hypochlorite. Microwave irradiation in combination with hypochlorite increases the reaction rate and efficiency of decolorisation. This effect is smaller in the case of RO16 dye but much pronounced in the case of AB111 dye. The microwave effect was also observed in the case of BY28 decolorisation. It was shown that thermal effect was observed when only hypochlorite was used. The enhancement of the decolorisation process was observed in each microwave treatment of the studied dyes. This difference is due to the microwave thermal effect on the rate and decolorisation efficiency of the used treatment. It should be pointed out that there is no difference in reactivity order of dyes in the reaction with pure hypochlorite or microwave/ /hypochlorite combination.

\section{Acknowledgement}

The work was supported by the Ministry of Education and Science of the Republic of Serbia under the research projects: Ol172013 and Ol172046.

\section{REFERENCES}

[1] A.E.Ghaly, R.Ananthashankar, M.Alhattab, V.V. Ramakrishnan (2014) Production, Characterization and Treatment of Textile Effluents: A Critical Review, Journal of Chemical Engineering \& Process Technology, 5(1), 1-19.

[2] X.J.Jenitta, V.D.V.Gnanasalomi, J.J.Gnanadoss (2013) Treatment of leather effluents and waste using fungi, International Journal of Computing Algorithm, 2, 294-298.

[3] J.Liu (2005) Papermaking technology evolution: its impact on wet-end retention, Paper Technology, 46(8), 31-36.

[4] A.Au, F.Dzulkafli (2012) Food Dyes Decolourized by pleurotus ostreatus, International Journal of Scientific and Research Publications, 2(4), 1-5.

[5] H.Zahir, M.Naidoo, R.Kostadinova, K.A.Ortiz, R.Sun-Kou, A.E.Navarro (2014) Decolorization of hair dye by lignocellulosic waste materials from contaminated waters, Frontiers in Environmental Science, 2(28), 1-7.

[6] Z.Zhang, Y.Xu, X.Ma, F.Li, D.Liu, Z.Chen, F.Zhang, D.D.Dionysiou (2012) Microwave degradation of methyl orange dye in aqueous solution in the presence of nano- $\mathrm{TiO}_{2}$-supported activated carbon (supported- $\mathrm{TiO}_{2} / \mathrm{AC} / \mathrm{MW}$ ), Journal of Hazardous Materials, 209-210, 271-277.

[7] C.A.Martinez-Huitle, E.Brillas (2009) Decontamination of wastewaters containing synthetic organic dyes by electrochemical methods: A general review, Applied Catalysis B: Environmental, 87(3-4), 105-145.

[8] P.Gregory (1990) Classification of Dyes by Chemical Structure, book Topics in Applied Chemistry, publisher Springer, p. 17-47.

[9] H.Zollinger (1987) Color Chemistry, VCH, Weinnheim.

[10] R.J.Chudgar, J.Oakes (2003) Dyes, Azo, in KirkOthmer Encyclopedia of Chemical Technology, Wiley, New York.

[11] P.F.Gordon, P.Gregory (1987) Organic chemistry in Colour, Springer-Verlag, Berlin.

[12] K.Singh, S.Arora (2011) Removal of Synthetic Textile Dyes From Wastewaters: A Critical Review on Present Treatment Technologies, Critical Reviews in Environmental Science and Technology, 41(9), 807-878.

[13] M.T.Yagub, T.K.Sen, S.Afroze, H.M.Ang (2014) Dye and its removal from aqueous solution by adsorption: A review, Advances in Colloid and Interface Science, 209, 172-184. 
[14] S.Suresh (2014) Treatment of Textile Dye Containing Effluents, Current Environmental Engineering, 1(3), 162-184.

[15] J.Oakes (2002) Principles of colour loss. Part 1: Mechanisms of oxidation of model azo dyes by detergent bleaches, Review of Progress in Coloration and Related Topics, 32(1), 63-79.

[16] D.Bogdal (2005) Microwave-assisted Organic Synthesis: One Hundred Reaction Procedures, Elsevier, Amsterdam.

[17] N.Wang, P.Wang (2016) Study and application status of microwave in organic wastewater, treatment - A review, Chemical Engineering Journal, 283, 193-214.

[18] S.Chandrasekaran, S.Ramanathan, T.Basak (2013) Microwave food processing-A review, Food Research International, 52(1), 243-261.

[19] T.Wu (2008) Environmental Perspectives of Microwave Applications as Remedial Alternatives: Review, Practice Periodical of Hazardous, Toxic and Radioactive Waste Management, 12(2), 102115.

[20] U.Riaz, S.M.Ashraf, M.Farooq (2015) Effect of pH on the microwave-assisted degradation of methyl orange using poly(1-naphthylamine) nanotubes in the absence of UV-Visible radiation, Colloid and Polymer Science, 293(4), 1035-1042.

[21] V.L.Gole, P.R.Gogate (2014) Degradation of brilliant green dye using combined treatment strategies based on different irradiations, Separation and Purification Technology, 133, 212220.

[22] S.Liu, J.Huang, Y.Ye, A.Zhang, L.Pan, X.Chen (2013) Microwave enhanced Fenton process for the removal of methylene blue from aqueous solution, Chemical Engineering Journal, 215-216, 586-590.

[23] T.Lai, K.Yong, J.Yu, J.Chen, Y.Shu, C.Wang (2011) High efficiency degradation of 4-nitrophenol by microwave-enhanced catalytic method, Journal of Hazardous Materials, 185(1), 366-372.

[24] X.D.Qi, Z.H.Li (2015) Efficiency optimization of a microwave-assisted Fenton-like process for the pretreatment of chemical synthetic pharmaceutical wastewater, Desalination and Water Treatment, in press.

[25] E.Sabah, M.S.Celik (2002) Interaction of pyridine derivatives with sepiolite, Journal of Colloid and Interface Science, 251, 33-38.

[26] S.Yang, P.Wang, X.Yang, G.Wei, W.Zhang, L.Shan (2009) A novel advanced oxidation process to degrade organic pollutants in wastewater: microwave-activated persulfate oxidation, Journal of Environmental Sciences, 21(9), 1175-1180.
[27] F.Parolin, U.M.Nascimento, E.B.Azevedo (2013) Microwave-enhanced $\mathrm{UV} / \mathrm{H}_{2} \mathrm{O}_{2}$ degradation of an azo dye (tartrazine): optimization, colour removal, mineralization and ecotoxicity, Environmental Technology, 34(10), 1247-1253.

[28] Y.Shui, H.Song, Z.Feng, Q.Li, Y.Jiang (2012) Study on decolorization for dye wastewater by adsorption - microwave degradation activated carbon from bean dregs, Advanced Materials Research, 581582, 214-218.

[29] P.S.Rathore, R.Patidar, S.Rathore, S.Thakore (2014) Nickel Nanoparticles as Efficient Catalyst for Electron Transfer Reactions, Catalysis Letters, 144(3), 439-446.

[30] B.A.Shah, A.V.Shah, C.B.Mistry, R.V.Tailor, H.D.Patel (2011) Surface Modified Bagasse Fly Ash Zeolites for Removal of Reactive Black-5, Journal of Dispersion Science and Technology, 32(9), 1247-1255.

[31] L.Zhang, X.Liu, X.Guo, M.Su, T.Xu, X.Song (2011) Investigation on the degradation of brilliant green induced oxidation by $\mathrm{NiFe}_{2} \mathrm{O}_{4}$ under microwave irradiation, Chemical Engineering Journal, 173(3), 737-742.

[32] U.Riaz, S.M.Ashraf, M.Aqib (2014) Microwaveassisted degradation of acid orange using a conjugated polymer, polyaniline, as catalyst, Arabian Journal of Chemistry, 7(1), 79-86.

[33] S.Shanthi, K.S.Priya (2013) Photodegradation of dyes from their aqueous solutions, using $\mathrm{TiO} 2$ as the oxidant with different sources of energy, Indian Journal of Environmental Protection, 33(3), 248253.

[34] J.M.Mirković, N.Ž.Prlainović, G.S.Ušćumlić, B.N. Grgur, D.Ž.Mijin (2014) Optimization of electrochemical decolorization of certain arylazo pyridone dyes, Journal of the Serbian Chemical Society, 79(12), 1523-1536.

[35] A.Kraft, M.Stadelmann, M.Blaschke, D.Kreysig, B.Sandt, F.Schroeder, J. Rennau (1999) Electrochemical water disinfection Part I: Hypochlorite production from very dilute chloride solutions, Journal of Applied Electrochemistry, 29(7), 859866

[36] J.Kotz, P.Treichel, J.Townsend, D.Treichel (2015) Chemistry \& Chemical Reactivity, Cengage learning, Stamford.

[37] D.Ž.Mijin, V.D.Tomić, B.N.Grgur (2015) Electrochemical decolorization of the Reactive Orange 16 dye using a dimensionally stable Ti/PtOx anode, Journal of Serbian Chemical Society, 80(7), 903915. 
[38] D.Ž.Mijin, M.L.Avramov Ivić, A.E.Onjia, B.N.Grgur (2012) Decolorization of textile dye Cl Basic Yellow 28 with electrochemically generated active chlorine, Chemical Engineering Journal, 204-206, 151-157.

[39] A.N.Diaz (1990) Absorption and emission spectroscopy and photochemistry of 1,10anthraquinone derivatives: a review, Journal of Photochemistry and Photobiology, A: Chemistry, 53(2), 141-167.

[40] H.Kanazawa, T.Onami (2001) Mechanism of the degradation of Orange $\mathrm{G}$ by sodium hypochlorite, Coloration Technology, 117(6), 323-327.

[41] T.Omura (1994) Design of chlorine-fast reactive dyes: Part 4: degradation of amino-containing azo dyes by sodium hypochlorite, Dyes and Pigments, 26(1), 33-50.

[42] V.Ya.Fain, B.E.Zaitsev, M.A.Ryabov (2009) Tautomerism of Anthraquinones: VIII.* Tautomerism and
Conformations of 1,4-Diamino-9,10-anthraquinone, Russian Journal of Organic Chemistry, 45(3), 374382.

[43] A. de la Hoz, A.Díaz-Ortiz, A.Moreno (2005) Microwaves in organic synthesis. Thermal and nonthermal microwave effects, Chemical Society Reviews, 34(2), 164-178.

[44] S.Horikoshi, A.Saitou, H.Hidaka, N.Serpone (2003) Environmental remediation by an integrated microwave/UV-illumination method. V. thermal and nonthermal effects of microwave radiation on the photocatalyst and on the photodegradation of Rhodamine-B under UV/Vis radiation, Environmental Science and Technology, 37(24), 5813-5822

[45] C.O.Kappe, B.Pieber, D.Dallinger (2013) Microwave Effects in Organic Synthesis: Myth or Reality, Angewandte Chemie International Edition, 52(4), 1088-1094.

\section{IZVOD}

\section{UTICAJ MIKROTALASNOG ZRAČENJA NA OBEZBOJAVANJE SINTETSKIH BOJA HIPOHLORITOM}

U okviru rada, tri sintetske boje tretirane su rastvorom hipohlorita ili kombinacijom rastvora hipohlorita $i$ mikrotalasnog zračenja, da bi se ispitao uticaj različitih faktora na obezbojavanje ispitivanih boja. Jedinjenja koja su korišćena u ispitivanju pripadaju azo (C.I. Reactive orange $16-$ RO16), azometinskim (C.I. Basic yellow 28 - BY28) i antrahinonskim bojama (C.I. Acid Blue $111-$ AB111). takođe je ispitivana stabilnost hipohlorita kako pri zagrevanju tako i pri mikrotalasnom zračenju.

Ključne reči: Obezbojavanje boja, natrijum-hlorid, azo boje, antrahinonske boje, azometinske boje, otpadna voda, mikrotalasni reactor.

Naučni rad

Rad primljen: 17.10.2015.

Rad prihvaćen: 30.11.2015.

Rad je dostupan na sajtu: www.idk.org.rs/casopis 